\title{
Geo-ecological characteristics of the small lakes bottom sediments in the North of Western Siberia
}

\author{
Gulnara N. Shigabaeva ${ }^{\bigotimes}$, Andrey V. Soromotin, Evgeny V. Galunin, \\ Anna V. Ruseikina, Anna A. Kurbash, Andrey E. Petrov, Alena D. Bashmachnikova \\ University of Tyumen, 6, Volodarsky St., Tyumen 625003, Russian Federation \\ g.n.shigabaeva@utmn.ru
}

\begin{abstract}
The article analyzes and provides data on the processes of accumulation of heavy metals by bottom sediments from the point of view of environmental assessment. The purpose of this paper is to identify the degree of anthropogenic influence on the lakes of the Tazovskiy and Surgut districts, and assess the ecological state of water bodies and adjacent territories. The main processes occurring in natural reservoirs, which lead to the transfer of toxicants into the environment, are considered. The data of quantitative chemical analysis of bottom sediments of two groups of natural reservoirs with an assessment of their ecological state according to the results of statistical processing of the measured values were obtained. Excess concentrations of metals were recorded: for mobile forms - 2200 times for $\mathrm{Fe}, 1050$ times for $\mathrm{Mn}, 35$ times for $\mathrm{Cr}$, 20 times for $\mathrm{Co}$, up to 15 times for $\mathrm{Ni}, 5$ times for $\mathrm{Cu}, 3$ times for $\mathrm{Pb}$, for acid-soluble forms -45000 times for $\mathrm{Fe}$, 550 times for $\mathrm{Pb}$, up to 75 times for $\mathrm{Ni}, 525$ times for $\mathrm{Mn}, 105$ times for $\mathrm{Cr}, 50$ times for $\mathrm{Cu}, 16$ times for $\mathrm{Co}$. The geochemical interpretation of the results of the factor analysis is presented.
\end{abstract}

Keywords: bottom sediments; environmental monitoring; heavy metals; factor analysis.

For citation: Shigabaeva GN, Soromotin AV, Galunin EV, Ruseikina AV, Kurbash AA, Petrov AE, Bashmachnikova AD. Geo-ecological characteristics of the small lakes bottom sediments in the North of Western Siberia. Journal of Advanced Materials and Technologies. 2021;6(4):299-307. DOI: 10.17277/jamt.2021.04.pp.299-307

\section{Геоэкологическая характеристика донных отложений малых озёр Севера Западной Сибири}

\author{
Г. Н. Шигабаева ${ }^{\bigotimes}$, А. В. Соромотин, Е. В. Галунин,
}

А. В. Русейкина, А. А. Курбаш, А. Е. Петров, А. Д. Башмачникова

Тюменский государственный университет, ул. Володарского, 6, Тюмень 625003, Российская Федерация

$$
\text { g.n.shigabaeva@utmn.ru }
$$

\begin{abstract}
Аннотация: В статье проанализированы и приведены литературные сведения о процессах аккумуляции тяжелых металлов донными отложениями с точки зрения экологической оценки. Целью настоящей работы является выявление степени антропогенного влияния на озёра Тазовского и Сургутского районов, оценка экологического состояния водоёмов и прилегающих к ним территорий. Рассмотрены основные процессы, идущие в природных водоёмах, которые приводят к переводу токсикантов в окружающую среду. Получены данные количественного химического анализа донных отложений двух групп природных водоёмов с оценкой их экологического состояния по результатам статистической обработки полученных значений. Зафиксированы превышения концентраций металлов: по подвижным формам - 2200 раз по $\mathrm{Fe}, 1050$ раз по $\mathrm{Mn}, 35$ раз по $\mathrm{Cr}$, в 20 раз по Co, до 15 раз по $\mathrm{Ni}$, в 5 раз по $\mathrm{Cu}$, в 3 раза по $\mathrm{Pb}$, по кислоторастворимым формам - 45000 раз по $\mathrm{Fe}, 550$ раз по $\mathrm{Pb}$, до 75 раз по Ni, 525 раз по Mn, 105 раз по $\mathrm{Cr}$, в 50 раз по $\mathrm{Cu}, 16$ раз по Со. Приведена геохимическая интерпретация результатов факторного анализа.
\end{abstract}

Ключевые слова: донные отложения; экологический мониторинг; тяжелые металлы; факторный анализ.

Для цитирования: Shigabaeva GN, Soromotin AV, Galunin EV, Ruseikina AV, Kurbash AA, Petrov AE, Bashmachnikova AD. Geo-ecological characteristics of the small lakes bottom sediments in the North of Western Siberia. Journal of Advanced Materials and Technologies. 2021;6(4):299-307. DOI: 10.17277/jamt.2021.04.pp.299-307 


\section{Introduction}

In the natural environment, including water bodies, lakes, and soils, the predominant factor is the accumulation of heavy metals by natural systems. However, the accumulation of pollutants outside, due to the migration of elements between forms without pronounced destruction or dispersal, is unlikely. From an ecological perspective the accumulative and biotoxic properties of elements have been of particular interest and widely described in a number of sources. Over a certain period of time the impact of human activity on natural landscapes has been aggravated, accumulations of heavy metals by water bodies have been observed, resulting in an increase in the background level as a whole [1-5].

Among all natural systems, water bodies are of greater interest due to migration processes, selfpurification and self-regulation processes occurring in them, which prevent the accumulation of pollutants and have a compensatory effect caused byre deposition and bioprocessing, thereby preventing the removal of contaminants into the near-water space. As a result of studying the accumulation of pollutants in the environment, much information can be obtained from studying lakes or their systems. However rivers and other waters with the presence of currents, there is a transfer of matter caused by the flow and, therefore, there is no possibility of tracking the continuity between the contents of pollutants for a long period of time between the layers of bottom sediments, and it is also impossible to accept the system as static. An important role is played by the final form of occurrence of metals in the environment, which can be a determining factor in potential toxicity to biota. As a result, to assess the ecological state of water bodies, it is necessary to identify the ratio of the content of water-soluble, acid-soluble, mobile or stable forms. It is extremely important to take into account the contribution of the possibility of migration processes between the above forms. All of the above indicates that the indicator of contamination of any system with harmful substances is influenced not only by the concentration of toxicants in its parts, but also by the form in which they are located, and also by the migration processes between these forms, directing pollutants towards more available, and as a consequence, more dangerous $[6,7]$.

Heavy metals, entering the water body in the form of ions, most likely pass into complexes with ligands of organic and inorganic nature, selfregulatory and self-purifying processes [3-7]. The properties of the area and the nature of the source, such as the $\mathrm{pH}$ of the environment, biological and climatic factors, play an important role in the composition of the final form of the metal entering the reservoir. Physical processes of diffusion in the soil mass, sedimentation processes, as well as the movement of bottom sediments contribute to the accumulation and adsorption of complexes by solid particles, which can occur directly in bottom sediments [8-12]. Biological processes, the death of aquatic organisms and aquatic vegetation have a noticeable effect [13].

Bed deposits include bottom sediments and other solid particles that have ended up on the bottom of a water body during subsidence, or such objects that have settled as a result of processes inside the reservoir. These include biochemical, physicochemical processes occurring in natural environments with various substances of natural and man-made origin [14]. As for the chemical, elemental, granulometric composition of bottom sediments and their distribution between parts of the reservoir, they are strictly individual for each object, and strongly depend on such factors as depth, bottom topography, and hydrodynamic conditions of the system (ebb and flow, surface and deep currents, unrest). In addition to the above, the composition and nature of sedimentary material and biological productivity of waters have a strong influenced [15].

Among the processes influencing the formation of bottom sediments, one can distinguish hydrological, climatic, physical, mechanical, biological, chemical and other processes. The sequence is as follows $[15,16]$ : the weathering of rocks occurs in the catchment area, the substance passes into a form that is available for migration, then it is washed off and carried by rain, melt, sewage or wind. Afterwards there is a process of separation of liquid and solid phases, during which the water goes into the reservoir, suspensions are precipitated and mixed; the processes of interaction with the soil and its loose formations take place. The processes occurring in the reservoir lead to the migration of organomineral substances, and chemical interactions of the organic and inorganic parts of the system occur. Further, a mixture of allochthonous and autochthonous substances is deposited under the influence of hydrodynamic, physicochemical and hydrobiological conditions; new layers of bottom sediments are layered on top of each other and settle to the bottom. Subsequently, this leads to the transformation of sediments into sedimentary rock and to the accumulation of pollutants-toxicants by bottom sediments. 
Sample preparation is of great importance in chemical analysis; it involves the extraction of heavy metals from bottom sediment samples. Extraction of substances is performed using solvents [16] - both destructive (for decomposition of the sample up to rock-forming oxides) and non-destructive soft reagents for obtaining solutions of relatively mobile forms of metals can be used. It should be noted that mobile forms, i.e. readily available forms, are the most significant in environmental assessment. These are water-soluble, exchangeable and acid-soluble forms. To assess the level of pollution and risks, it is necessary to know the content of mobile forms of metals, which are bioavailable to the biota of water bodies, precisely at $\mathrm{pH}=4.8$. Acid-soluble forms of heavy metals content can be considered the gross content, since heavy metals have poor sorption on a mineral basis. Quantitative chemical analysis shows that the total content and the content of acid-soluble forms differ insignificantly.

This paper discusses the results of a quantitative analysis of the content of heavy metals in samples of bottom sediments of lakes in the Surgut district of the Tyumen region as an oil production area and lakes in the Tazovskiy district, which can be classified as potentially unpolluted. The following tasks were set:

1) to conduct a chemical analysis of bottom sediment samples for the content of heavy metals (acid-soluble and mobile forms) using the standard method of atomic absorption spectroscopy;

2) to compare the results obtained with the values regulated by regulatory documents (approximate / maximum permissible concentrations (APC / MPC)), for objects subject to anthropogenic stress from the oil industry;

3) to subject the data to factor analysis and interpretation using Goldschmidt's geochemical classifications, showing the geochemical affinity of the naturalness or anthropogenicity of the system, assess the presence/absence of significant anthropogenic pressure on objects in terms of compliance with geochemical laws.

\section{Materials and Methods}

The content of heavy metals $\left(\mu \mathrm{g} \cdot \mathrm{dm}^{-3}\right)$ in the extracts of bottom sediments was determined by atomic absorption analysis, all measurements were carried out using an atomic absorption spectrophotometer 700 Analytik Jena ${ }^{\mathrm{TM}}$ ContrAA, using electrothermal and flame methods of sample atomization. Extracts were prepared using standard techniques [17-19]. The results of the chemical analysis were obtained using the equipment of the
Shared Use Center of the Shared Use of Natural Resources and Physical and Chemical Research Center of Tyumen State University.

Samples were taken by the Research Institute "Rational Use of Natural Resources" staff of Tyumen State University and the Research Institute of Ecology in September 2018, from two districts of the Tyumen region: Tazovskiy (Fig. 1) and Surgut (Fig. 2). The lakes of the Tazovskiy district of the Yamalo-Nenets Autonomous Okrug are located in the tundra region, most likely in this area there is no significant man-madeimpact. Samples were taken from the coastal water-side part of the bottom at a depth of $15 \mathrm{~cm}$, six thermokarstral lakes of the Tazovskiy peninsula. These lakes are located far from oil and gas production sites and settlements (see Fig. 1). The reservoirs of the Surgut district of the Khanty-Mansi Autonomous Okrug (see Fig. 2) are located in oil production areas, near highways and are most likely subject to anthropogenic pressure. In terms of shape and size, the lakes under study are thermokarst lakes of the same genesis. The samples of bottom sediments of lakes of similar genesis and parent rock (Fig. 3), located in the same climatic conditions, but at some distance from the studied ones, were selected as a background object.

Determination of the content of mobile forms of elements was carried out according to the method $[17,18]$. A portion of an air-dry soil sample weighing $5.00 \mathrm{~g}$ was weighed on an analytical balance directly into a conical flask with a capacity of $100 \mathrm{ml}$. A cylinder was poured into a sample of the bottom sediment $50 \mathrm{ml}$ of an acetate-ammonium buffer solution with $\mathrm{pH}=4.8$ (the ratio of bottom sediment: solution $=1: 10$ ). Covering the flask with a lid and gently stirring, it was left for $24 \mathrm{~h}$ at room temperature, and the sample was stirred for each hour. One day later, the extract was filtered on a funnel with a paper folded filter "white tape". The extract was filtered directly into a volumetric flask, quantitatively washing off the residue on the filter with a buffer solution. Then the volumetric flask was brought to the mark $(100 \mathrm{ml})$ with the same buffer solution and mixed thoroughly. In the text of the article, the mobile form of the metal is designated as $n$-Me.

The content of acid-soluble forms of elements was carried out according to the method [17, 19]. A $2 \mathrm{~g}$ portion of an air-dry sample was weighed on an analytical balance directly into a $50 \mathrm{ml}$ conical flask. Bottom sediment samples with $10 \mathrm{ml}$ of $5 \mathrm{M}$ nitric acid (soil: acid ratio $=1: 5$ ) were poured onto the sample with a cylinder and the sample was mixed. 

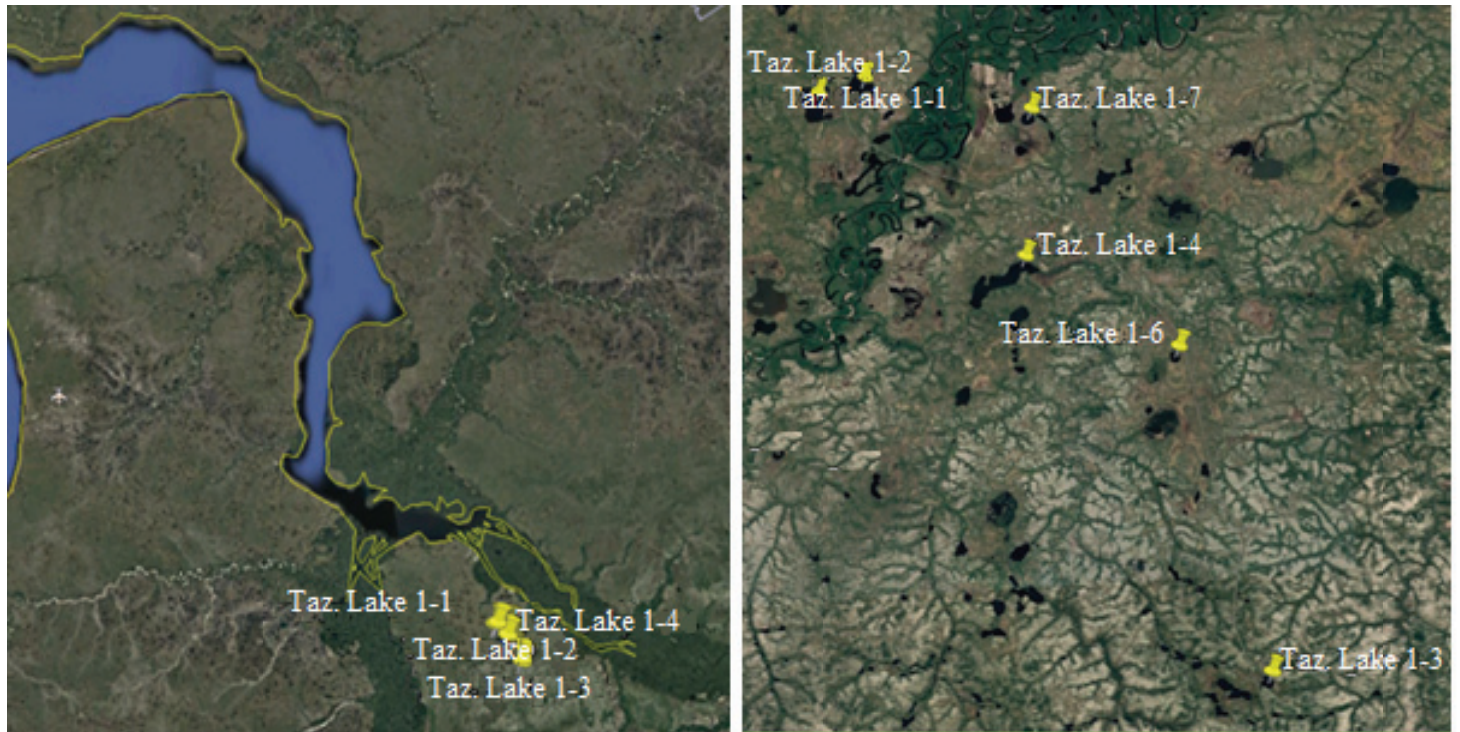

Fig. 1. Sampling sites located on the Tazovskiy peninsula

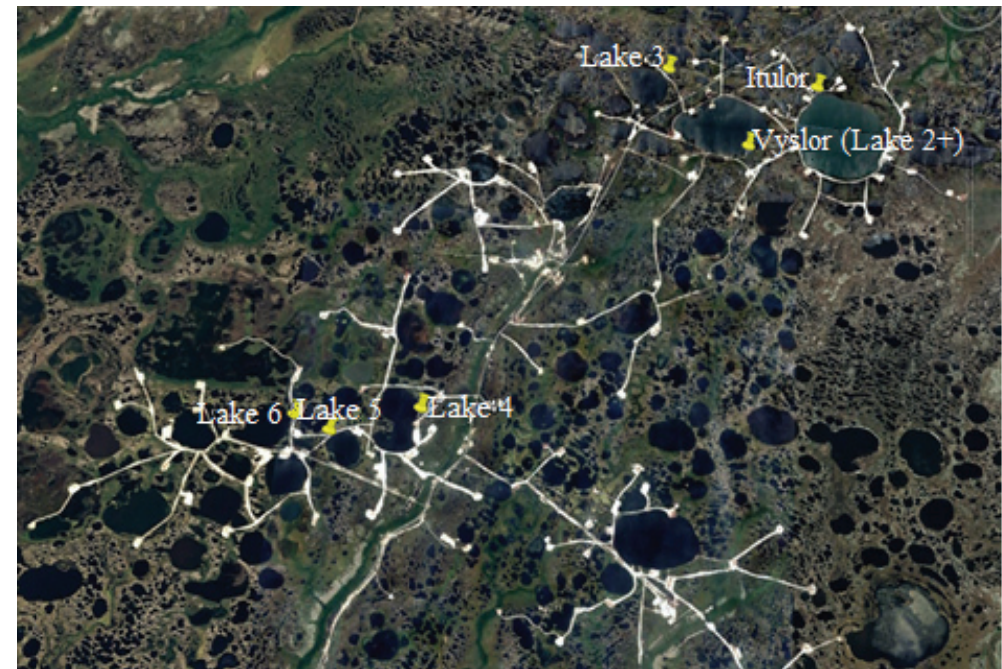

Fig. 2. Sampling sites located in the Surgut district
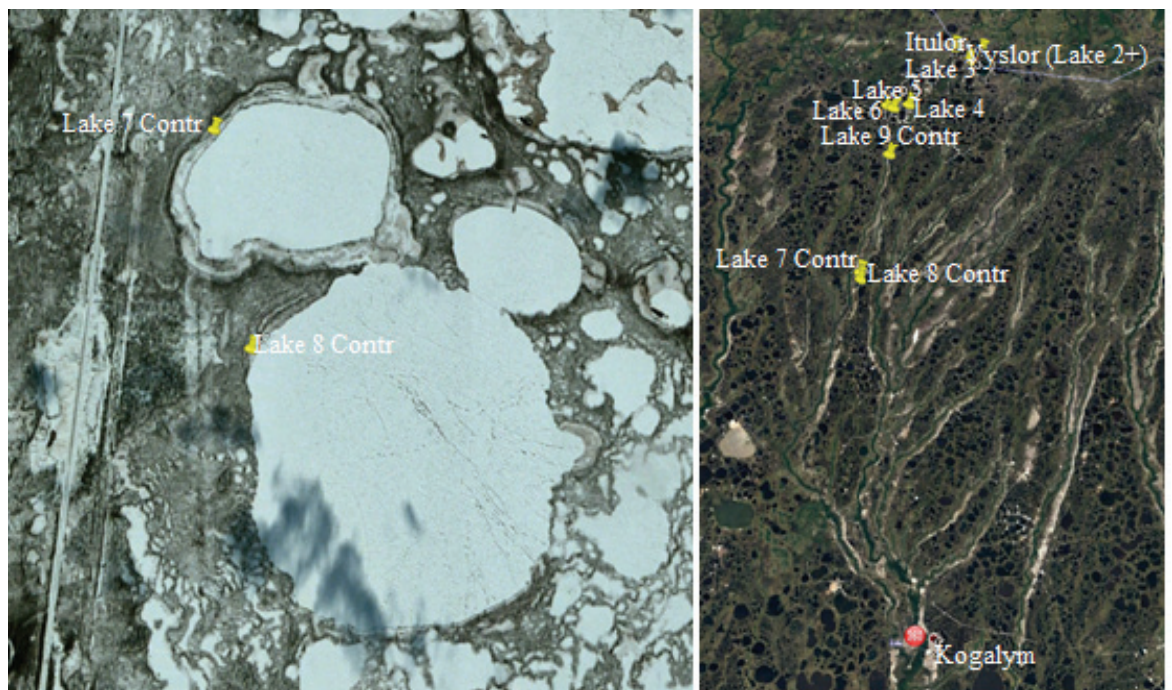

Fig. 3. Sampling sites of the background lakes 
The flask was covered with plastic wrap; epy holes were pierced for the outlet of evaporating nitric acid and placed in a boiling water bath for 3 hours, stirring every hour with low-intensity circular movements. Then the mixture was left to cool to room temperature, and filtered through a filter with a "blue" ribbon, quantitatively rinsing from the filter with distilled water, about $30 \mathrm{ml}$. Then it was brought to the mark $(50 \mathrm{ml})$ with distilled water and mixed thoroughly.

All measurements on the spectrophotometer were carried out in parallel.

The determined element in the sediment sample was calculated for each determination $\left(X_{i}\right), \mathrm{mg} \cdot \mathrm{kg}^{-1}$, according to the formula (1):

$$
X_{i}=\frac{\left(C_{\mathrm{m} i}-C_{X}\right) V k}{m},
$$

where $C_{\mathrm{m} i}$ is mass concentration of an element in the analyzed solution, $\mathrm{mg} \cdot \mathrm{dm}^{-3} ; \quad C_{X}$ is mass concentration of an element in a blank solution, $\mathrm{mg} \cdot \mathrm{dm}^{-3} ; V$ is solution volume; $k$ is dilution factor if present; $m$ is weight of the bottom sediment sample, $g$.

\section{Results and Discussion}

\subsection{Results of measurements of the concentrations of metals in bottom sediments in the Tazovskiy district}

Some samples of bottom sediments were taken in the Tazovskiy district of the Yamalo-Nenets Autonomous Okrug beyond the Arctic Circle, from six lakes. There are no large settlements in this area, and it can be considered relatively clean in terms of anthropogenic pressure from the oil industry.

Other samples were taken from the thermokarst lakes of the tundra region, located far from settlements and large industries, but having a possible influence from the side of a nearby highway. For their analysis, we used the material of the coastal drive part of the bottom at a depth of $15 \mathrm{~cm}$.

The data obtained from the chemical analysis of heavy metals in the samples from the Tazovskiy peninsula were compared with the available APC and MPC for soils (Methodical instructions 2.1.7.730-99, Hygiene standards 2.1.7.2042-06) [20, 21]. An excess of the values for manganese $(185,170,594$ and $190 \mathrm{mg} \cdot \mathrm{kg}^{-1}$ from APC $=100 \mathrm{mg} \cdot \mathrm{kg}^{-1}$ for 4 samples) in compliance with by regulatory documents was recorded. However, according to these data, it is impossible to unambiguously judge the presence of an anthropogenic component, since the natural increased background for manganese is characteristic of Western Siberia. For the rest of the metals, the MPC was not exceeded, the clarke was not exceeded either; thus it can be concluded that at the current moment the state of the lakes is not hazardous to human health and biota in general.

Then, using the Statistica 6.0 software, the data were subjected to mathematical statistical processing using correlation and factor analysis. Significant correlation values were found for pairs: $\mathrm{Mn}-n-\mathrm{Mn}$ (0.77), $\mathrm{Cr}-\mathrm{Fe}$ (0.62), $\mathrm{Mn}-n-\mathrm{Cu}$ (0.61), $\mathrm{Cr}-\mathrm{Co}$ (0.73), $\mathrm{Fe}-n$ - Mn (0.76), $\mathrm{Ni}-n$ - Ni (0.71), $\mathrm{Pb}-n$ - $\mathrm{Cr}$ (0.67), $\mathrm{Ni}-\mathrm{Co}$ (0.86 and 0.81). Obviously, there is a significant correlation between nickel and cobalt, belonging to the group of siderophilic elements according to Goldschmidt's classification. There is a clear and obvious relationship between the various forms of the content of manganese and nickel. The excess content of manganese in the samples is characteristic of the soils of Western Siberia, and this fact is also confirmed. Moreover, a distribution between its forms is observed, which does not contradict the geochemical distributions in nature. Pairs of elements from different geochemical groups: chromium-lead, chromium-cobalt, manganesecopper, chromium-iron, iron-manganese, also correlate, but this contradicts Goldmidt's classification. Therefore, it can be assumed that in this case the process of sorption of metals on the minerals forming the rock, oxides of chromium, iron and manganese, is limited.

It is possible to more clearly interpret the data and draw conclusions using factor analysis (Fig. $4 a$ ).

The factor analysis graph for the full array of experimental data is overloaded, but the siderophilic group (cobalt, nickel in two forms) is clearly detected, which is obviously well described by factor 2 .

The second factor is suitable for describing the distribution of manganese, chromium and iron. Lead and other chalcophilic elements located in the center of the graph show complete indifference to factors, which cannot be said about siderophilic and lithophilic elements.

When separately considering the distribution of mobile forms of metals, two characteristic groups are clearly visible on the graph of factor loadings (Fig. 4b). The central chalcophilic elements and nickel are influenced by factor 2, while lithophilic chromium, manganese and iron are influenced by factor 1. It can be concluded that the organic component is described by factor 2 , and the mineral part is described by factor 1 . 


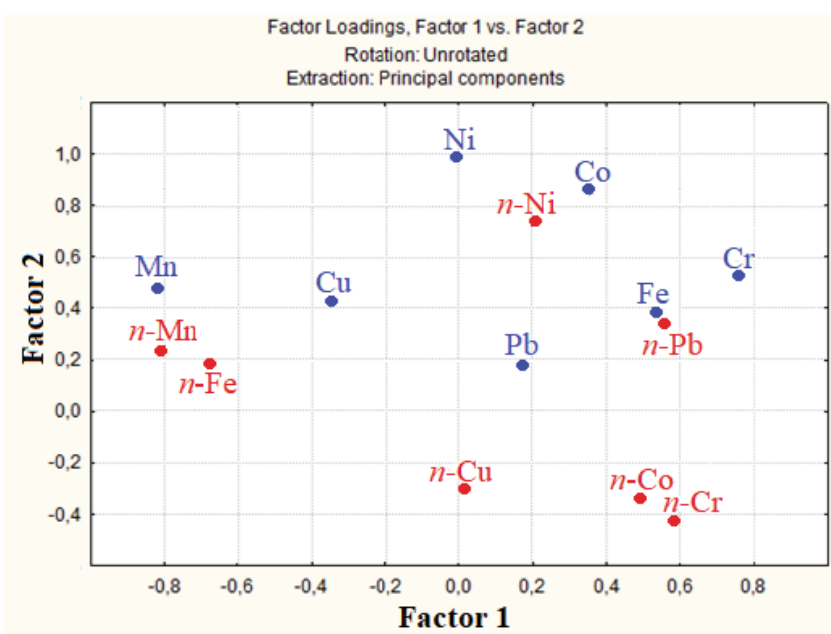

(a)

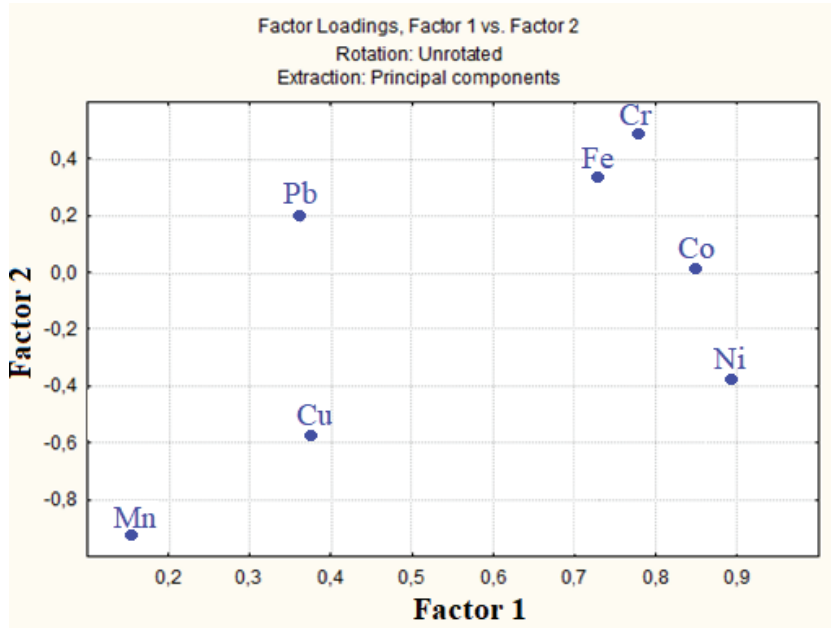

(c)

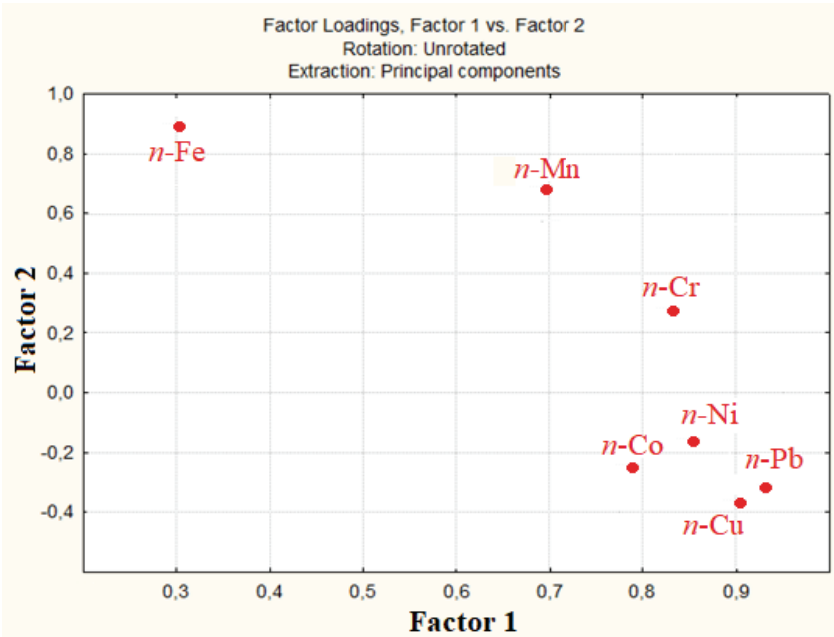

(e)

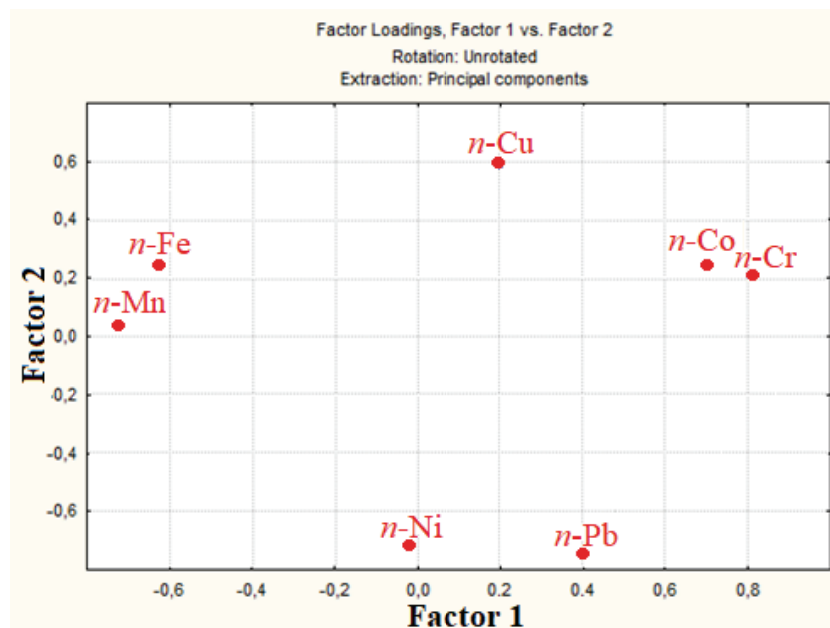

(b)

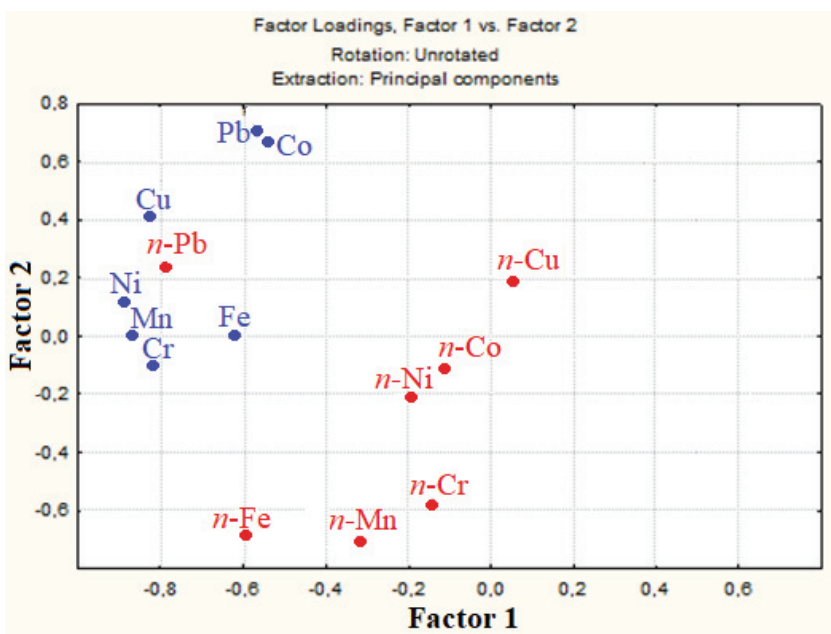

(d)

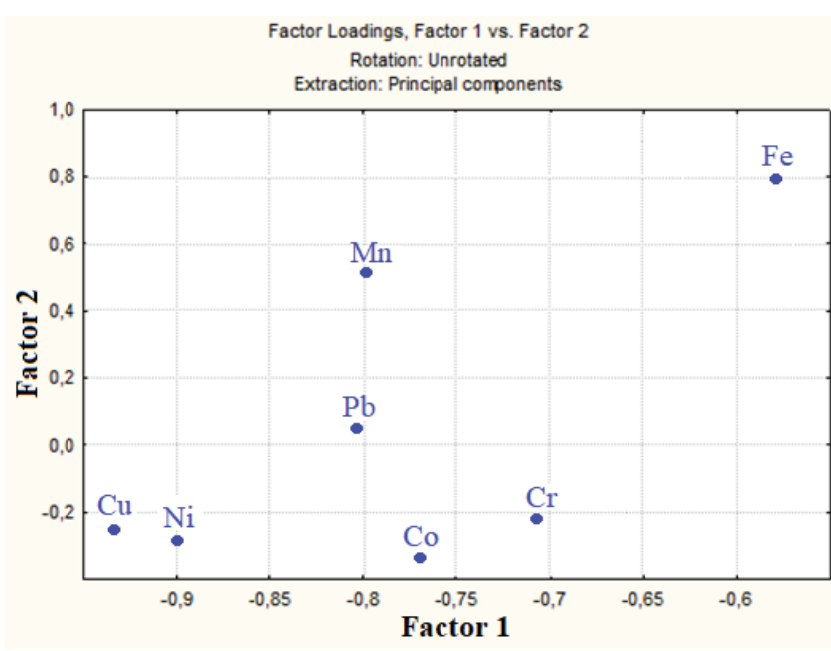

(f)

Fig. 4. Factor loadings

$a$ - the Tazovskiy peninsula, all fractions; $b$ - the Tazovskiy peninsula, mobile forms;

$c$ - the Tazovskiy peninsula, acid soluble forms; $d$ - the Surgut district, all fractions; $e$ - the Surgut district, mobile forms; $f$ - the Surgut district, acid soluble forms 
The factor loadings graph for acid-soluble forms is relatively simple (Fig. 4c). The first factor describes iron, cobalt, nickel and chromium, while factor 2 does not have a significant effect. Competition in accumulation processes and high manganese content in samples explains the differences observed in the behavior of manganese and iron. The loadings of both factors are insignificant for chalcophile elements, lead and copper.

Thus, the type of distributions of factor loadings, taking into account the correlation analysis carried out earlier, indicates the presence of two natural factors. One has a significant effect on the elements of the siderophilic group, and the second one - on the elements of the lithophilic group. In this case, chalcophilic elements occupy a separate place. The regularities of the behavior of elements in the natural environment known in geochemistry are confirmed by the results of factor analysis. The highest correlation values were found within geochemical groups (siderophilic, chalcophilic, and lithophilic), as well as between the forms of one element.

In samples of bottom sediments of lakes in the Tazovskiy district, point excess in manganese was revealed (from 1.5 and 6 times). However, the statistical analysis showed full agreement with the theoretical regularities of the behavior of elements in geochemistry (there are high correlations between elements of similar geochemical groups and within one element $\mathrm{Ni}-n$ - $\mathrm{Ni}(0.72), \mathrm{Ni}-\mathrm{Co}(0.87$ и 0.82$)$, $\mathrm{Mn}-n$-Mn (0.78). In addition, low values for the content of other elements enable to conclude that the studied water bodies are unpolluted, and they can be treated as background.

\subsection{Results of measurements of the concentrations of metals in bottom sediments in the Surgut district}

The results of a quantitative chemical analysis of samples of bottom sediments of lakes in the Surgut district of the Khanty-Mansi Autonomous Okrug were similarly compared with the APC and MPC for soils. At one point for manganese (1.5 times) and at two points for lead (2.6 times), excess of the MPC norms was revealed. For the rest of the metals, the indicators do not go beyond the MPC. Thus, the lakes can be considered unpolluted. However, the contents obtained for the background lakes are much lower, therefore, there is a possibility of anthropogenic impact on the studied lakes.

The graph shows (Fig. 4d) that significant influences are experienced by the pairs: $n-\mathrm{Cr}-n-\mathrm{Mn}$,
$n$-Fe; $\mathrm{Co}-\mathrm{Pb}, \mathrm{Cr}, \mathrm{Mn}, \mathrm{Fe} ; \kappa-\mathrm{Ni}-\mathrm{Cu}, n-\mathrm{Pb}, \mathrm{Cr}, \mathrm{Mn}$, $\mathrm{Fe} ; \mathrm{Cu}-\mathrm{Co}, \mathrm{Pb}, \mathrm{Mn}, \mathrm{Fe} ; n-\mathrm{Pb}$ with a number of elements $\mathrm{Ni}, \mathrm{Cu}, \mathrm{Co}, \kappa-\mathrm{Pb}, \mathrm{Cr}, \mathrm{Mn} ; \mathrm{Pb}-\mathrm{Mn}, \mathrm{Mn}-\mathrm{Fe}$. Consequently, metals correlate both within the same geochemical groups according to Goldschmidt's classification, and within pairs of different forms of the same metal. This fact may indicate the completeness of the element extraction. In addition to the described sets of correlations, the massif has several other sets, the interpretation of which from the point of view of geochemical correlations is much more difficult due to the different chemical nature of the elements under consideration. It can be argued that there are correlations that contradict Goldschmidt's classification. Presumably, there are anthropogenic sources of these elements entering the water bodies, especially since it was said earlier that there are exceeding the standards for these elements.

The factor loadings graph for interpretation is simple but massive. It can be seen that most of the specific indicators are well influenced by factor two and are located on the vertical relative to it. At the same time, mobile forms are not very susceptible to the influence of factors and are manifested within a separate group.

For mobile forms of metals, the diagrams of distributions of factor loadings are easier to interpret (Fig. 4e). On the right side of the graph, under the high dependence on factor one, there is a large group of elements. The pair wise character is manifested for chalcophilic (lead and copper) and siderophilic (cobalt and nickel). At the same time, the massif contains metals of different geochemical groups, which suggests an anthropogenic source of the influx of metals into this environment, since such a distribution cannot be substantiated from a geochemical point of view. Iron shows antagonism in relation to the rest of the mass and at the same time experiences a high loading factor from factor 2, like manganese. In the massif, factor 1 describes most of the elements similar to the samples from the Tazovskiy district, while factor 2 is associated with the processes of iron sorption on manganese oxides. Indeed, in nature they are often found in the form of ferromanganese nodules.

The graph for acid-soluble forms again demonstrates elements of different geochemical nature, which is very difficult to interpret (Fig. 4f). Iron occupies a separate position relative to the elements of the siderophilic group. Chalcophilic, lithophilic elements are located close to each other. The higher the content of the element in the hoods, the greater the influence of factor 2 is. Factor 1 affects all metals with a high correlation coefficient, 
regardless of their content. This distribution also indicates the anthropogenic nature of the introduction of elements into the lakes.

The lakes of the Surgut district, with the exception of several excess for one point for manganese (1.5 times) and two points for lead (1.5, 2.6 times) in comparison with the MPC are unpolluted and not hazardous for biota. The results of the statistical analysis contradict the natural distribution, which unambiguously indicates the possibility of anthropogenic pressure of nearby oilextracting enterprises on water bodies.

\section{Conclusions}

1. When evaluating the results of quantitative chemical analysis of samples of bottom sediments of two objects, from the Tazovskiy peninsula and from the Surgut district, for the content of heavy metals, occasional excess of the MPC for lead (2.6 times) and manganese ( 2 and one-time 6 times) were revealedin the samples from the Surgut district.

2. When evaluating the results of quantitative chemical analysis of samples of bottom sediments of the Surgut district, the obtained values were compared with the obtained concentrations in the background lakes of the same territories. Significant excess of metal concentrations in polluted lakes was recorded: for mobile forms -2200 times for $\mathrm{Fe}, 1050$ times for $\mathrm{Mn}, 35$ times for $\mathrm{Cr}, 20$ times for Co, up to 15 times for $\mathrm{Ni}, 5$ times for $\mathrm{Cu}, 3$ times for $\mathrm{Pb}$, for acid-soluble forms - 45000 times for $\mathrm{Fe}, 550$ times for $\mathrm{Pb}$, up to 75 times for $\mathrm{Ni}, 525$ times for $\mathrm{Mn}, 105$ times for $\mathrm{Cr}$, 50 times for $\mathrm{Cu}, 16$ times for $\mathrm{Co}$.

3. Geochemically explainable groups of elements with similar values of factor loadings in the samples from the Tazovskiy peninsula were identified and visual complex distributions of similar loadings were obtained for samples from the Surgut region, which indicate the possibility of anthropogenic influences on the water bodies of the Surgut district.

4. The lakes of the Tazovskiy peninsula can be classified as unpolluted in terms of anthropogenic pressure, but the water bodies in the Surgut district as subject to anthropogenic pressure due to the presence of pair correlations of metals.

\section{Funding}

This research received no external funding.

\section{Conflict of interests}

The authors declare no conflict of interest.

\section{References}

1. Briffa J, Sinagra E, Blundell R. Heavy metal pollution in the environment and their toxicological effects on humans. Heliyon. 2020;6(8):e04691. DOI:10.1016/ j.heliyon.2020.e04691

2. Ahmad W, Alharthy RD, Zubair M, Ahmed M, Hameed A, Rafique S. Toxic and heavy metals contamination assessment in soil and water to evaluate human health risk. Scientific Reports. 2021;11:17006. DOI:10.1038/s41598-021-94616-4

3. Wuana RA, Okieimen FE. Heavy metals in contaminated soils: A review of sources, chemistry, risks and best available strategies for remediation. International Scholarly Research Notices. 2011;2011:402647. DOI:10.5402/2011/402647

4. Izmailova AV. Water resources of the lakes of the Russian Federation. Geografiya $i$ prirodnye resursy $=$ Geography and Natural Resources. 2016;4:5-14. DOI:10.21782/GIPR0206-1619-2016-4(5-14) (In Russ.)

5. Kremleva TA, Moiseenko TI, Khoroshavin VY, Shavnin AA. Geochemical features of natural waters in Western Siberia: trace element composition. Vestnik Tyumenskogo gosudarstvennogo universiteta. Ekologiya $i$ prirodopol'zovaniye. 2012;12:80-89. (In Russ.)

6. Hadzi GY, Essumang DK, Ayoko GA. Assessment of contamination and health risk of heavy metals in selected water bodies around gold mining areas in Ghana. Environmental Monitoring and Assessment. 2018;190:406. DOI:10.1007/s10661-018-6750-Z

7. Zhou Q, Yan N, Li Y, Ren B, Ding X, Bian H, Yao X. Total concentrations and sources of heavy metal pollution in global river and lake water bodies from 1972 to 2017. Global Ecology and Conservation. 2020;22:e00925. DOI:10.1016/j.gecco.2020.e00925

8. Davydova OA, Klimov EU, Vaganova EU, Vaganov AS. The impact of physicochemical factors on the content of heavy metals in aquatic ecosystems. Ulyanovsk: Ulyanovsk State Technical University publ.; 2014. 167 p. (In Russ.).

9. Lezin VA. Water resources of rivers and lakes of the Tyumen region. Vestnik Tyumenskogo gosudarstvennogo universiteta. 2011;12:62-69. (In Russ.).

10. Nikanorov AM. Hydrochemistry. SaintPetersburg: Hydrometeoizdat. Ekologiya i prirodopol'zovaniye; 2001. 444 p. (In Russ.).

11. Hoang H-G, Lin C, Tran H-T, Chiang C-F, Bui X-T, Kiprotich Cheruiyot N, Shern C-C, Lee C-W. Heavy metal contamination trends in surface water and sediments of a river in a highly-industrialized region. Environmental Technology \& Innovation. 2020;20:101043. DOI:10.1016/j.eti.2020.101043

12. Moiseenko TI, Panicheva LP, Dinu MI, Kremleva TA, Fefilov NN. Inactivation of toxic metals in land waters by humic substances. Vestnik Tyumenskogo gosudarstvennogo universiteta. 2011;5:6-19. (In Russ.).

13. Moiseenko TI, Gashkina NA. Formation of the chemical composition of lake waters under conditions of environmental changes. Moscow: Science. Geophysical sciences; 2010. 266 p. (In Russ.). 
14. Soviet Standard GOST 17.1.5.01-80. Nature protection. Hydrosphere. General requirements for sampling of bottom sediments of water objects for their pollution analysis. Moscow: IPK Publishing House of Standards; 1982. (In Russ.).

15. Tarkovsky AA. Geochemistry of bottom sediments of modern lakes. Leningrad: Leningrad University Press. Geochemistry; 1980. 172 p. (In Russ.).

16. Vodyanitskiy YN. Methods for sequential extraction of heavy metals from soils - new approaches and mineralogical control (analytical review). Pochvovedenie =Eurasian Soil Science. 2006;10:11901199. (In Russ.).

17. M-MVI-80-2008. Methods for measuring the mass fraction of elements in soil, soil and bottom sediments samples by atomic emission and atomic absorption spectrometry. Saint-Petersburg: VNIIM named after D. Mendeleev; 2008. (In Russ.).

18. Guidance Document RD 52.18.289-90. Methodical instructions. Methods for measuring the mass fraction of mobile forms of metals (copper, lead, zinc, nickel, cadmium, cobalt, chromium, manganese) in soil samples by the atomic absorption method. Moscow: USSR State Committee for Hydrometeorology; 1990. (In Russ.).

$$
\text { 19. Guidance Document RD 52.18.191-89. }
$$

Methodical instructions. Methods for measuring the mass fraction of acid-soluble forms of metals (copper, lead, nickel, cadmium) in soil samples by atomic absorption analysis. Moscow: USSR State Committee for Hydrometeorology; 1990. (In Russ.).

20. Tigeev AA. Features of the soil cover of the Khylmigyakha river basin (Nadym-Purovsky interfluves). Vestnik Tyumenskogo gosudarstvennogo universiteta. 2014;4:39-48. (In Russ.).

21. Shamilishvili GA, Abakumov EV, Pechkin AS. Features of the soil cover of the Nadym region. Scientific Vestnik of the Yamalo-Nenets Autonomous Okrug. Ecology of the Arctic. 2016;4(93):12-16.(In Russ.).

\section{Информация об авторах / Information about the authors}

Шигабаева Гульнара Нургаллаевна, кандидат технических наук, профессор, заведующий кафедры органической и экологической химии, ФГАОУ ВО «Тюменский государственный университет», Тюмень, Российская Федерация; ORCID 0000-0002-0368-1943; e-mail: g.n.shigabaeva@utmn.ru

Соромотин Андрей Владимирович, доктор биологических наук, доцент, профессор, ФГАОУ ВО «Тюменский государственный университет», Тюмень, Российская Федерация; ORCID 0000-0002-7771-4592; e-mail: a.v.soromotin@utmn.ru

Галунин Евгений Валерьевич, Ph.D., доцент, ФГАОУ ВО «Тюменский государственный университет», Тюмень, Российская Федерация; ORCID 00000002-8219-0148; e-mail: e.v.galunin@utmn.ru

Русейкина Анна Валерьевна, кандидат химических наук, доцент, профессор, ФГАОУ ВО «Тюменский государственный университет», Тюмень, Российская Федерация; ORCID 0000-0003-0757-0922; e-mail: a.v.rusejkina@utmn.ru

Анна Андреевна Курбаш, ассистент, ФГАОУ ВО «Тюменский государственный университет», Тюмень, Российская Федерация; ORCID 0000-0002-3804-1081; e-mail: a.a.kurbash@utmn.ru

Петров Андрей Евгеньевич, студент, ФГАОУ ВО «Тюменский государственный университет», Тюмень, Российская Федерация; ORCID 0000-0001-7081-9124; e-mail: stud0000228082@study.utmn.ru

Башмачникова Алёна Денисовна, студент, ФГАОУ ВО «Тюменский государственный университет», Тюмень, Российская Федерация; ORCID 0000-00015708-707X; e-mail: korolyowaaleona@yandex.ru
Gulnara N. Shigabaeva, Cand. Sc. (Engineering), Professor, Head of the Department of Organic and Ecological Chemistry, University of Tyumen, Tyumen, Russian Federation; ORCID 0000-0002-0368-1943; e-mail: g.n.shigabaeva@utmn.ru

Andrei V. Soromotin, D. Sc. (Biology), Associate Professor, Professor, University of Tyumen, Tyumen, Russian Federation; ORCID 0000-0002-7771-4592; e-mail: a.v.soromotin@utmn.ru

Evgeny V. Galunin, Ph.D., Associate Professor, University of Tyumen, Tyumen, Russian Federation; ORCID 0000-0002-8219-0148;

e-mail: e.v.galunin@utmn.ru

Anna V. Ruseikina, Cand. Sc. (Chemistry), Associate Professor, Professor, University of Tyumen, Tyumen, Russian Federation; ORCID 0000-0003-0757-0922; e-mail: a.v.rusejkina@utmn.ru

Anna A. Kurbash, Assistant, University of Tyumen, Tyumen, Russian Federation; ORCID 0000-0002-38041081; e-mail: a.a.kurbash@utmn.ru

Andrey E. Petrov, Student, University of Tyumen, Tyumen, Russian Federation; ORCID 0000-0001-70819124; e-mail: stud0000228082@study.utmn.ru

Alena D. Bashmachnikova, Student, University of Tyumen, Tyumen, Russian Federation; ORCID 00000001-5708-707X; e-mail: korolyowaaleona@yandex.ru

Received 04 October 2021; Accepted 29 November 2021; Published 28 December 2021

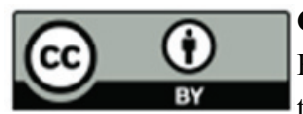

Copyright: (C) Shigabaeva GN, Soromotin AV, Galunin EV, Ruseikina AV, Kurbash AA, Petrov AE, Bashmachnikova AD, 2021. This article is an open access article distributed under the terms and conditions of the Creative Commons Attribution (CC BY) license (https://creativecommons.org/licenses/by/4.0/). 